\title{
Potrzeba rozumienia i aktualizacji pojęcia godności osoby ludzkiej wobec współczesnych zagrożeń związanych z ludzkim życiem
}

Właściwe rozumienie godności osoby w obliczu wyzwań współczesnej medycyny staje się dziś tematem naglącym. W obecnym porządku prawnym promuje się tę wartość jako podstawę nowoczesnego społeczeństwa, w którym jest miejsce na wolność, równość oraz szacunek przysługujący każdej jednostce ludzkiej. Potwierdzają to dokumenty o międzynarodowej randze, jak również szereg praw nadanych człowiekowi dla jego ochrony. Pojęcie godności znalazło należne sobie miejsce stając się podstawą praw pacjenta. Jednak zapisy prawne nie gwarantują obecnie, jak należało by się spodziewać, należytej ochrony w sytuacjach zagrożenia zdrowia i życia ludzkiego. Trudno doszukać się w nich klarownego odwołania do kryterium godności rozumianego w sposób jednoznaczny. Pomimo, że odwołanie się do godności stanowi akceptowaną formę uzasadnienia w bioetyce, to w dynamicznie rozwijającym się obszarze biomedycyny łatwo stracić ją z pola widzenia. Stąd istnieje potrzeba właściwego rozumienia i aktualizacji pojęcia godności, aby nie wyczerpywała się jedynie w katach prawnych, jako pusta formuła.

\section{Problematyka wiarygodności pojęcia godności w debacie bioetycznej}

W dobie dynamicznego rozwoju biomedycyny i postępu naukowego powstaje problem nie tylko sposobu rozumienia pojęcia godności, ale przede wszystkim jej wiarygodności. W prowadzonych debatach bioetycznych uwidacznia się następująca tendencja: zamiast pytania o to, czy metody współczesnej medycyny nie godzą w godność człowieka, debatuje się nad tym, czy nasze rozumienie godności ludzkiej odpowiada możliwościom czy też osiągnięciom nauki. Jak pisze H. Juros: Pojęcie osoby ludzkiej należy nadal do języka bioetyki, chociaż dla wielu adwersarzy staje się pojęciem niewygodnym ${ }^{1}$.

H. JuRos, Godnościowa argumentacja w debacie bioetycznej [w:] Europejskie dylematy i paradygmaty, Warszawa 2003, s. 235. 
Trudności interpretacyjne związane z pojęciem godności i jej aplikacją do konkretnych w sytuacji problemowych skutkuje sformułowaniem szeregu zarzutów pod jej adresem. Bioetycy polscy (W. Bołoz, F. J. Mazurek, H. Juros, M. Środa $)^{2}$ wymieniają następujące zarzuty:

- brak ogólnie akceptowanej teorii godności (niebezpieczeństwo dowolnej interpretacji);

- uboga treść pojęcia godności (treść pojęcia godności nadaje jej charakter projektujący, tzn. tworzy etykę obarczoną pewną dowolnością i niedookreślonością, co z kolei nadaje tej etyce charakter osobisty);

- egoizm uprawiania etyki godności (człowiek jako istota uprzywilejowana)

pojęcie godności stanowi „hamulec bezpieczeństwa” wobec dynamicznego rozwoju nauk przyrodniczych;

- brak rozróżniania rodzajów godności nie sprzyja debacie bioetycznej (chaos terminologiczny).

\section{Klasyfikacja pojęcia godności}

Aby móc zmierzyć się z powyższymi zarzutami należy wrócić do źródeł godności. Na odczytywanie godności mają wpływ różne czynniki - pozytywne, związane z systemami filozoficznymi, religią i kulturą oraz czynniki negatywne, które utożsamiać należy z wszelkimi aktami barbarzyństwa i ludobójstwa. Ponadto godność można ujmować w aspekcie filozoficznym, socjologicznym, psychologicznym, prawnym i teologicznym. Również uwarunkowania zachowań godnościowych można podzielić na dwie grupy. Zewnętrzne, do których należą m.in. uwarunkowania historyczne, ekonomiczne oraz społeczno-polityczne oraz uwarunkowania wewnętrzne, przynależące do sfery psychiczno-emocjonalnej człowieka, związane z postawą moralną i stylem życia. ${ }^{4}$

Powyższe trudności nie zniechęcają jednak do poszukiwania właściwego rozumienia godności. Podejmuje się wciąż bardziej lub mniej udane próby klasyfikacji tego pojęcia.

Wielu autorów o orientacji personalistycznej prezentuje pogląd o wrodzoności i niezbywalności godności. ${ }^{5}$ Godność jest wówczas wartością uniwersalną, nienaruszalną, której nie możemy utracić, ponieważ jej nadanie nie pochodzi

2 Por. W. BoŁoz, Bioetyka i prawa człowieka, Warszawa 2007, s. 57, 65; F. J. MAZUrek, Godność osoby ludzkiej podstawa praw człowieka, Lublin 2001, s. 71-75; H. Juros, tamże; M. ŚrodA, Idea godności w kulturze i etyce, Warszawa 1993, s. 182nn.

3 Twierdzenie, że pojęcie godności jest „ubogie w treść” chroni je przed uznaniem jako pojęcia systemowego, tzn. przynależącego do konkretnego systemu filozoficznego, co rodziłoby dające się łatwo przewidzieć konsekwencje.

4 Por. J. Gajda, Honor, godność, człowieczeństwo, Lublin 2000, s. 65.

5 Por. F. J. Mazurek, dz. cyt., s. 14. 
bezpośrednio od człowieka. Tymczasem koncepcje utylitarystyczne ukazują godność jako wartość indywidualną i nabytą, a przez to utracalną, naruszalną. Zgodnie z tym podziałem wyróżniamy godność osobową (dignity of person) od godności osobowościowej (personal dignity). Godność wrodzona stanowić będzie źródło praw. Godność nabyta kojarzona będzie natomiast z pewnym stałym dążeniem człowieka do doskonałości. ${ }^{6}$ Najlepiej koncepcje godności traktować integralnie ${ }^{7}$ i uzupełniająco. Nie oznacza to jednak, by stosować te je wymiennie. Treść godności pozostaje w pewnym stopniu dalej niedookreślona, co otwiera duże możliwości wartościowania i stopniowania godności. Różne rozumienie godności nie usuwa jednak z myślenia społecznego głębokiego przekonania, że godność ma pierwszeństwo wobec innych interesów oraz wyższość nad wszelkimi innymi dobrami (nie podlega rachunkowi dóbr) ${ }^{8}$. Dlaczego zatem pewności aksjologicznej związanej z przyznaniem człowiekowi godności, jako wartości nienaruszalnej, towarzyszy niepewność co do jej treści i konkretyzacji?

\section{Godność w pułapce utylitaryzmu}

Zapisy dotyczące wrodzonego charakteru godności możemy odnaleźć w wielu dokumentach międzynarodowych m.in Powszechna Deklaracja Praw Człowieka, Powszechna Deklaracja Praw Człowieka, Karta Praw podstawowych Unii Europejskiej, Konstytucja RP. Widoczna jest natomiast tendencja, aby absolutną ochronę ludzkiej godności znacznie ograniczyć, a jednocześnie zarezerwować dla sfery najwyższych przejawów człowieczeństwa. Takie zabiegi czyni z powodzeniem doktryna utylitaryzmu, która znalazła szerokie grono zwolenników na całym świecie. Rezygnacja $\mathrm{z}$ bezwarunkowego roszczenia godności poprzez jego banalizację i zawężenie do konkretnych jednostek - osób znosi opierającą się na godności ochronę człowieka. Pojawia się wówczas problem praktycznego zastosowania tej podstawowej wartości konstytucyjnej.

W etyce godnościowej na pierwszym miejscu znajduje się człowiek i jego dobro. Nie należy mylić dobra $\mathrm{z}$ utylitarystycznym dążeniem do maksymalizacji szczęścia, które w istocie je udaremnia. Nie można budować właściwej etyki tam, gdzie dyskryminacja określonej grupy osób (na podstawie niejasno sprecyzowanych kryteriów) nie przyczynia się do pomnażania korzyści i szczęścia, ale wywołuje uczucie lęku i strachu w społeczeństwie. Bagatelizacja samego czło-

6 Taki podział wprowadza m.in. M. Piechowiak, źródło: referat Godność jako fundament praw człowieka wygłoszony na konferencji Refleksja filozoficzna nad prawami człowieka w Europie środkowo - wschodniej w II połowie XX wieku, Uniwersytet Kardynała Stefana Wyszyńskiego w Warszawie, 13 V 2009.

7 Wrodzona godność osoby ludzkiej jest podstawą i zarazem wymogiem nabywania godności osobowościowej.

8 Por. E. Picker, Godność człowieka a życie ludzkie, Warszawa 2007, s. 6-9. 
wieka, którą prezentuje utylitaryzm rysuje się wyraźnie w sytuacji, kiedy „szkodę wyrządzoną ofierze usprawiedliwia się korzyścią jej adresata"'. Interes osób trzecich stawia się ponad interes jednostki, na podstawie subiektywnych wyobrażeń aksjologicznych. Godność będzie wówczas pełnić funkcję dobra użyczonego, tak jak prawo do życia zostanie zastąpione prawem do odmowy drugiemu życia.

Etyka utylitaryzmu jest o tyle niebezpieczna, że jej przesłanki są perswazyjne i przemawiają do sfery ludzkich uczuć. Propozycja łatwego dostępu do szczęścia, poczucia satysfakcji z racji kreowania rzeczywistości, przy jednoczesnym zapewnieniu o likwidacji poczucia bezradności i niemocy, jest w obecnych czasach bardzo przemawiające. Retoryka utylitaryzmu jest bardzo sugestywna (por. wyrażenie dotyczące godnej śmierci). Dopiero głębsza analiza odsłania ukryte przesłanki oraz wewnętrzne sprzeczności tej doktryny. Niemniej jednak nie należy lekceważyć utylitaryzmu, którego fenomen polega na przemyślanej „grze językowej”, która w sposób zakamuflowany prowadzi do zastanowienia się czy relatywizacja sfery związanej z ludzkim życiem i godnością osoby ludzkiej poprzez wywoływanie w odbiorcy uczuć czystego, bezinteresownego współczucia, nie jest zabiegiem nie tyle koniecznym, co wskazanym i pożądanym społecznie. Zapoczątkowana przez utylitaryzm praktyka zniesienia hierarchii dóbr i wartości zrewolucjonizowała współczesne myślenie, kładąc nacisk na efektywność i skuteczność ludzkiego działania, bez konieczności odwoływania się do norm moralnych, w tym podstawowej wartości, jaką stanowi godność.

\section{Problem utożsamiania godności z wolnością}

W etyce poszanowania dla życia ludzkiego nie powinno zabraknąć właściwego rozumienia pojęcia wolności (autonomii jednostki ludzkiej) oraz właściwego rozumienia relacji pomiędzy tymi pojęciami. Niestety rozumienie godności ucierpiało przez połączenie go $\mathrm{z}$ pojęciem autonomii. W dziedzinie etyki pojęcie autonomii wprowadził I. Kant ${ }^{10}$, rozumiejąc ją jako autonomię woli, która jest dla siebie prawem, toteż stanowi ona element samookreślający człowieka, $\mathrm{z}$ uwzględnieniem powszechnej zasady moralnej wyrażającej się w imperatywie kategorycznym ${ }^{11}$. Współcześnie ten uniwersalny element przy definiowaniu

E. Picker, dz. cyt., s. 135.

10 W. Tatarkiewicz, Historia Filozofii, t. 2, Warszawa 1983, s. 178.

11 Imperatyw kategoryczny I. Kanta brzmi następująco: „Postępuj wedle takiej zasady, co do której masz pewność, że stanie się ona prawem powszechnym”. „Traktuj człowieka jako cel sam w sobie, nigdy zaś jako środek do celu" Imperatyw kategoryczny stanowi sąd rozumu praktycznego o charakterze uniwersalnym, pozwalającym na ocenę ludzkiego postępowania w dziedzinie moralności. Pełni również rolę wzorca, do którego należy dostosowywać wszelkie zasady regulujące ludzkie postępowanie, gdzie istota ludzka pełni funkcję centralną (nie może być traktowana jako środek do uzyskania celu). 
pojęcia wolności jest w dyskusjach bioetycznych pomijany, a zastępuje się go rozumieniem autonomii jako prawa i możliwości dokonywania wolnego wyboru. Utożsamianie godności z tak przyjętą definicją autonomii rodzi zrozumiałe obawy. Absolutyzacja pojęcia autonomii jednostki ludzkiej prowadzić musi do negacji drugiego człowieka, a nawet paradoksalnie negacji samego siebie, jako czynnika wpływającego na ograniczanie tejże autonomii ${ }^{12}$. „Dla wolności nie istnieją żadne inne granice poza nią samą"13 - pisał J. Sartre. Problem niewłaściwie pojmowanej, nieograniczonej wolności rodzi przyzwolenie na budowanie społeczeństwa opartego na przemocy (gdzie rządzi prawo silniejszego). Całkowicie suwerenna wolność bez żadnych odniesień i ograniczeń determinuje w sposób autonomiczny ludzkie działanie, kładąc nacisk na jednostkę jako kreatora treści poszczególnych norm moralnych. W sposób dowolny człowiek zyskuje prawo do decydowania o tym, co dobre i złe, słuszne i niesłuszne, co stanowi wartość, a co nią nie jest. Opierając prawo na tak rozumianej autonomii jednostki (gdzie jednostka stanowi fundament tego prawa), tworzy się umowy społeczne oderwane od związków i rzeczywistości obiektywnych, skrajnie relatywne i dostosowane do zmieniających się społecznych tendencji. Tam, gdzie uprawnienia do tworzenia podstaw życia społecznego ma wyłącznie autonomia jednostki, tam prawo nie odnosi się do społeczeństwa, ale jego uprzywilejowanych grup i jednostek.

Wolność, aby być autentyczna, musi posiadać odniesienie do świata wartości, zatem nie może omijać godności, ponieważ jest ona wartością wartości. Autonomię należy prawidłowo rozumieć w sensie uniwersalizmu. Człowiek działa w sposób wolny, jeżeli jego czyny są zgodne z prawem moralnym ${ }^{14}$. Wolność jako prawo wszystkich ludzi musi być realizowana w społeczeństwie, co stanowi jej warunek. Nie oznacza to jednak rezygnacji z roli jednostki w budowaniu życia społecznego opartego na godności. Nie może być bowiem moralności pozaosobowej, ani też praw moralnych, które nie odwoływały by się ostatecznie do dobra osoby. Godność osoby w porządku społeczno - moralnym rozumieć należy jako współzależność moralności społecznej i osobowej.

\section{Etyka bez godności}

Godność określana bywa jako atrybut przynależny powszechnie. Znajdują się jednak głosy przemawiające za tym, by pojęcie godności z etyki zastąpić pojęciem szacunku ${ }^{15}$. A. Gregorczyk uważa, że pojęcie godności jest zbędne i jest

12 A. Muszla, Medycyna a globalizacja, Kraków 2003, s. 184

13 Tamże, s. 151 [za:] J. P. SARTre, L'etre let le neant. Essai d'ontology phenomenologique, Paris 1955, s. 514.

14 Por. F. J Mazurek, dz. cyt., s. 39.

15 Por. A. Gregorczyк, Wszyscy chcemy być ważni i niezależni, „Polityka” 28 (1982), s. 71. 
przejawem mnożenia bytów bez potrzeby ${ }^{16}$. Wiedza o wyższości człowieka nad światem zwierzęcym nie powstała na skutek badań naukowych, lecz za sprawą ideologii, w której ocenę dodano do opisu. Człowiek mieniący się godnością skoncentrowany na strukturze własnego ja, pogłębia antagonizmy w społeczeństwie, do których autor zalicza m.in. wykluczanie kompromisu, dyskryminację drugiego człowieka, powodowanie skłonności do generalizacji i kontrastowości ocen, sprzyjanie postawom egoistycznym oraz wzbudzanie roszczeniowości ${ }^{17}$. Niemniej jednak autor docenia pozytywne inspiracje godności, przy czym rezerwuje dla niej obszar etyki pedagogicznej.

Warto zauważyć, że dewiacje, o których wspomina autor godzą właśnie w godność człowieka. Inni autorzy (Z. Zalewski, Z. Chlewiński) wykazują, że nie poczucie godności powoduje deformację, ale to właśnie deformacja godności spowodowana jest przez przewartościowanie określonego elementu, prowadząc do różnego rodzaju egocentryzmów oraz powstawania szowinizmów ${ }^{18}$. Istotnym jest, że dewiacje w życiu moralnym powodują zaburzenia w przeżywaniu własnej godności. Propozycja utworzenia etyki bez pojęcia godności, a opartej na odczuciach wartości (tj. szacunku) wydaje się zabiegiem chybionym. Tak, jak odczucia godności różnią się od siebie, tak pojęcie szacunku różni się u różnych osób i jest narażone na dewiacje. Ponadto należy wyraźnie oddzielić poczucie godności, o którym pisze Gregorczyk, od pojęcia godności w ogóle. Przeżycie godności nie wytwarza prawdy o niej, lecz jedynie ją ujawnia. Nie tworzy jednak żadnego kryterium godności. Zdolność do przeżywania własnej godności nie stanowi zatem istoty pojęcia godności, przez co nie może stać się podstawą do negacji pojęcia godności w obowiązującym porządku moralno - prawnym.

\section{Propozycja aktualizacji pojęcia godności jako wymóg szczególny naszych czasów - podsumowanie}

Jak bronić godności osoby ludzkiej wobec współczesnych zagrożeń wynikających z dynamicznego rozwoju medycyny i nauk biologicznych? Godność osoby ludzkiej - pisze F. J. Mazurek - należy rozumieć jako wartość ontyczną, która jako wrodzona, trwała, niezbywalna staje się zobowiązująca ${ }^{19}$. Staje się jednocześnie podstawą fundamentalnych praw człowieka oraz równości pomiędzy ludźmi. Źródłem godności jest sam człowiek jako byt obdarzony naturą rozumną, człowiek widziany jako indywiduum, jako cel sam w sobie. Jeżeli natomiast prawo opierać się będzie na etyce, odwołującej się jedynie do godności rozumianej

16 Tenże, Pojęcie godności jako element poznawczej regulacji ludzkiego zachowania, „Studia Filozoficzne" 8-9 (1983), s. 58.

17 Por. tenże, Wszyscy..., s. 72.

18 Z. Chlewiński, Z. Zalewski, Godność, [w:] Encyklopedia katolicka, t. 5, Lublin 1989, kol. 1232

19 F. J. MaZurek, dz. cyt., s. 18. 
jako godność osobowościowa, daje to podstawę do relatywizacji wartości człowieka, a co za tym idzie przyzwolenia na praktyki naruszające szacunek wobec ludzkiego zdrowia i życia.

Wydaje się słuszne, aby mówiąc o pojęciu godności wyodrębniać jej podstawę, treść oraz zakres ochrony. Podstawę godności człowieka możemy odnaleźć powołując się na ludzką rozumną naturę, treść pojęcia godności powinna zostać każdorazowo konstruowana w oparciu o podstawę godności (co nie oznacza dowolnej jej interpretacji, a jedynie realizację godności w stosunku do osoby ludzkiej), co przekładało by się w sposób wyraźny na zakres ochrony osoby ludzkiej w sytuacjach zagrożenia. Panuje zgoda co do tego, że człowiekowi nie nadaje się praw, lecz uznaje ich istnienie, jako że są one wpisane w godność osoby ludzkiej, z której są odczytywane. Godność stanowi zatem fundament istnienia praw człowieka, stąd odbieranie godności rangi uniwersalnej zasady moralności godzi również w prawa człowieka. Należałoby dołożyć wszelkich starań o to, by społeczne myślenie o godności nie wyczerpywało się $\mathrm{w}$ abstrakcyjnych aktach prawnych, ale miało realne przełożenie na sytuacje, w których życie ludzkie jest zagrożone. Istota prawa znajduje swoje odbicie $\mathrm{w}$ tendencjach społecznych zapisywanych $\mathrm{w}$ formie regulacji, stąd prawo ma relację wtórną wobec sfery moralności.

Zatem aktualizacja pojęcia godności odbywać się musi w takim znaczeniu, że patrząc przez pryzmat szacunku wobec osoby ludzkiej i jej życia dokonuje się sformułowania właściwej oceny etycznej określonych działań i ich następstw. Godność jest pierwszą, naczelną wartością stojącą na straży interesu zachowania zdrowia i życia każdej indywidualnej jednostki ludzkiej, ale nie wyczerpuje ona innych możliwości uzasadnień. Potrzebne są dalsze normy moralne, dające usprawiedliwienie dla podejmowanych praktyk w dziedzinie biologii, biotechnologii i medycyny, aby postęp naukowy (w tym i prawo) służyły człowiekowi, a nie przeciwko niemu. 